Bangladesh J. Bot. 47(4): 903-909, 2018 (December)

\title{
CALCIUM ALGINATE ENTRAPMENT OF ASPERGILLUS NIDULANS IMPP-0785 LACCASE FOR ENHANCED ENZYME CATALYTIC ABILITY, THERMOST ABILITY AND DYE-DECOLORIZATION
}

\author{
Malik Muhammad Yousaf, Muhammad Majeed ${ }^{1 *}$, Mumtaz Hussain, Muhammad \\ Jahangir Shah, Bashir Ahmad, Hafiz Muhammad Zia Ullah Ghazali ${ }^{2}$ \\ AND Rao Wali MUHAMMAD ${ }^{3}$
}

Arid Zone Research Institute (AZRI), Bahawalpur, Pakistan

Keywords: Laccase, Aspergillus nidulans IMPP-0785, Optimal conditions

\begin{abstract}
Production of laccase using a solid-state culture of Aspergillus nidulans IMPP-0785 was optimized using barley bran. Aspergillus nidulans IMPP-0785 laccase optimum activity was observed with filtrate $(29.15 \mathrm{U} / \mathrm{g})$ as compared to supernatant and unfiltered. Free laccase and supernatant gave best results at 30.24 and $25.95 \mathrm{U} / \mathrm{g}$, respectively for $20 \mathrm{~min}$ incubation time. The entrapped spores of A. nidulans IMPP-0785 showed maximal activity $(16.12 \mathrm{U} / \mathrm{g})$ at incubation time for $60 \mathrm{~min}$. Immobilized laccase resulted optimal activity $(29.24 \mathrm{U} / \mathrm{g})$ for $25 \mathrm{~min}$ of incubation. Enzyme showed higher thermo stability of $34.28 \mathrm{U} / \mathrm{g}$ when incubated for $35 \mathrm{~min}$.
\end{abstract}

\section{Introduction}

Laccases are common enzyme in nature. The first laccase was reported by Wesenberg et al. 2003) from Rhusvernicifera (Basidiomycetes) and white rot fungi laccase was derived (Viswanath et al. 2008). Laccases depend on $\mathrm{Cu}$ altos in their characteristic electronic paramagnetic resonance (EPR) signals (Bento et al. 2006). Laccases have been reported to have several applications including bioleaching (Arias et al. 2003), removal of phenolics, xenobiotics, and other aromatic compounds (Duran and Esposito 2000).

They can perform functions of pharmaceutical (Mehdi et al.2012), dye-degradation (Nyanhongo et al. 2002) and detoxification of industrial dyes. These enzymes are used for pulp delignification, pesticide or insecticide degradation, organic synthesis, waste detoxification, textile dye transformation, food technological uses, biosensor and analytical applications. These enzymes have significant HIV-1 reverse transcriptase activity (Harris et al. 2004).

Over the last two decades use of laccase has been explored for bioremediation of xenobiotics such as endocrine disrupting compounds (EDCs) for bleaching in pulp and paper industry, decolonization of azo dyes in textile industry ( Sinirlioglu et al. 2013). They dominate the dyestuff market with share of about $70 \%$, used for enzyme immobilization on solid materials and gels, low stability and productivity and high production costs, adsorption, entrapment of enzymes (Gupta and Suhas 2009). Fermentation types are; Submerged fermentation (SmF) and Solid state fermentation (SSF) (Elisashvili et al. 2008). The physical methods involve adsorption, entrapment of enzymes in insoluble polymeric gels (polymeric entrapment) or in micelles (encapsulation) (Duran et al. 2002).

\section{Materials and Methods}

Aspergillus nidulans IMPP-0785 was isolated and identified in the Department of Botany, University of Gujarat. The fungal strain was stored on barley bran extract medium with $15 \mathrm{~g}$ agar

\footnotetext{
"Author for correspondence: <majeedmohl@yahoo.com>. ${ }^{1}$ Department of Botany University of Gujrat, Gujrat. ${ }^{2}$ Assistant Plant Pathologist, Oilseed Research Station Khanpur Postal Code: 64100; ${ }^{3}$ Senior Scientific Officer, PARC research and training Station, BZU Multan. Postal Code: 66000
} 
per liter at $4{ }^{\circ} \mathrm{C}$ and homogenous suspension was put in another test tube. Haemocytometer was used for spore count and found to be $2.15 \times 10^{7} \mathrm{CFU} / \mathrm{ml}$. One hundred g of dried agar was added in $500 \mathrm{ml}$ cotton-plugged Erlenmeyer flasks with $100 \mathrm{ml}$ of $0.1 \mathrm{~N} \mathrm{HCl}$ and autoclaved at $15 \mathrm{lbs} / \mathrm{in}^{2}$ pressure $\left(121^{\circ} \mathrm{C}\right)$ for 15 min to attain the predesigned moisture content. Contents were mixed thoroughly by keeping the flask in a shaking incubator at $200 \mathrm{rpm}$ for $1 \mathrm{hr}$ and centrifuged at 3,000 rpm for 20 min. Laccase activity was determined by following method enzyme extract $(1 \mathrm{ml}), 0.5 \mathrm{ml}$ of $50 \mathrm{mM}$ sodium acetate buffer $(\mathrm{pH} 5)$ and $0.1 \mathrm{ml}$ of $1 \mu \mathrm{M}$ PDC were taken in a glass cuvette.

$$
\text { Laccase activity }(\mathrm{U} / \mathrm{g})=\frac{\mathrm{A}_{470 \mathrm{~nm}} \times \mathrm{DF} \times \mathrm{V}_{1}}{\text { Substrate }(\mathrm{g})} \frac{\mathrm{V}_{2}}{\Delta \mathrm{T}}
$$

where, $\mathrm{A}_{470 \mathrm{~nm}}$ is value of absorbance, $\mathrm{DF}$ (dilution factor), $\mathrm{V}_{1}$ (volume of reaction mixture in glass cuvette), $\mathrm{V}_{2}$ (volume of extract added) and $\Delta \mathrm{T}$ (time of incubation).

Spores of $A$. nidulans IMPP-0785 were immobilized by taking $3 \%$ of sodium alginate solution, for $30 \mathrm{~min}$ at $45^{\circ} \mathrm{C}$ in darkness at $620 \mathrm{~nm}$ (Sinirlioglu et al. 2013).

Dye decolorization $(\%)=\frac{(\text { Initial absorbance }- \text { final absorbance })}{\text { Initial absorbance }} \times 100$

Treatment effects were compared by the protected least difference method (Spss-21, version4, USA). Significance difference among the replicates has been presented as DMRT in the form of probability $(\mathrm{p})$ value.

\section{Results and Discussion}

Two batch cultures were run parallel from which batch-1 diluted with $200 \mathrm{ml}$ distilled water and batch-2 with $400 \mathrm{ml}$ distilled water to find out dilution effect on laccase production of $A$. nidulans IMPP-0785 (Fig. 1). The less activity (7.65 U/g) was observed with supernatant of batch2. A significant $(\mathrm{p} \leq 0.05)$ higher activity $(29.15$ and $27.46 \mathrm{U} / \mathrm{g})$ was obtained with batch-1 and batch-2 filtrate, respectively.

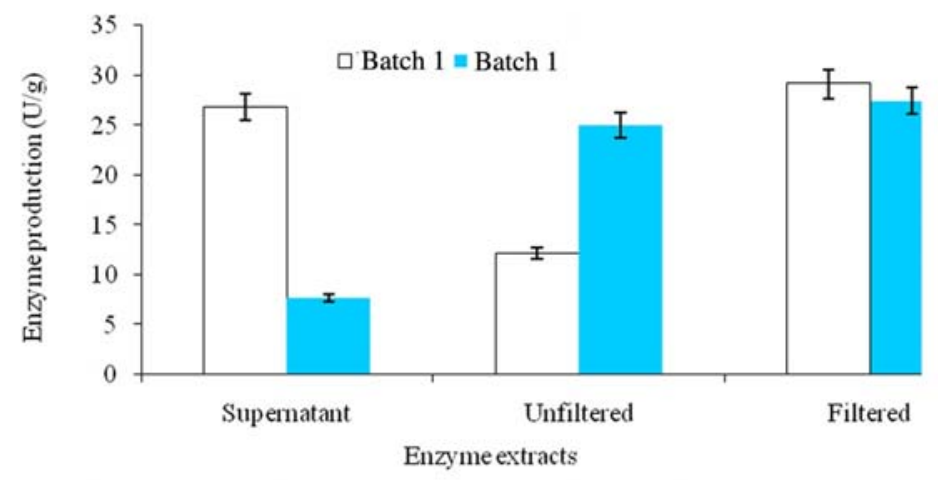

Fig. 1. Dilution effect on laccase production of A. nidulans IMPP-0785.

The rate of laccase production from A. nidulans IMPP-0785 in SSF was studied (Fig. 2). The enzyme stability was recorded to a maximal of $25.95 \mathrm{U} / \mathrm{g}$ with supernatant and $30.24 \mathrm{U} / \mathrm{g}$ for crude enzyme. Afterwards, enzyme stability was declined gradually up to $23.98 \mathrm{U} / \mathrm{g}$ with filtered crude enzyme. Hence, 20 min time of incubation was optimized for enzyme production. 
The effect of incubation period $(5,10,15,20,25,30,35$ and $40 \mathrm{~min})$ on laccase production was studied in sodium acetate buffer and $1 \mu \mathrm{m}$ of PDC solution (at $620 \mathrm{~nm}$ ), highest enzyme activity (20, 40,60, 80, 100 and $120 \mathrm{~min}$ ) (Fig. 3). Best results in terms of enzyme activity achieved $(29.24 \mathrm{U} / \mathrm{g})$ when incubated for $25 \mathrm{~min}$. Enzyme production declined gradually up to $10.02 \mathrm{U} / \mathrm{g}$ at an incubation of $40 \mathrm{~min}$. Hence, $25 \mathrm{~min}$ time of incubation was optimized as holding time for maximal enzyme activity.

The effect of incubation temperature (Fig. 4) at different temperature $(15,20,25,30,35,40$, $45,50,55$ and $\left.60^{\circ} \mathrm{C}\right)$ was applied to observe enzyme activity. A maximal enzyme activity $(34.28$ $\mathrm{U} / \mathrm{g})$ was found when incubated temperature was $35^{\circ} \mathrm{C}$ and minimal $(6.66 \mathrm{U} / \mathrm{g})$ was achieved when temperature was raised up to $55^{\circ} \mathrm{C}$.

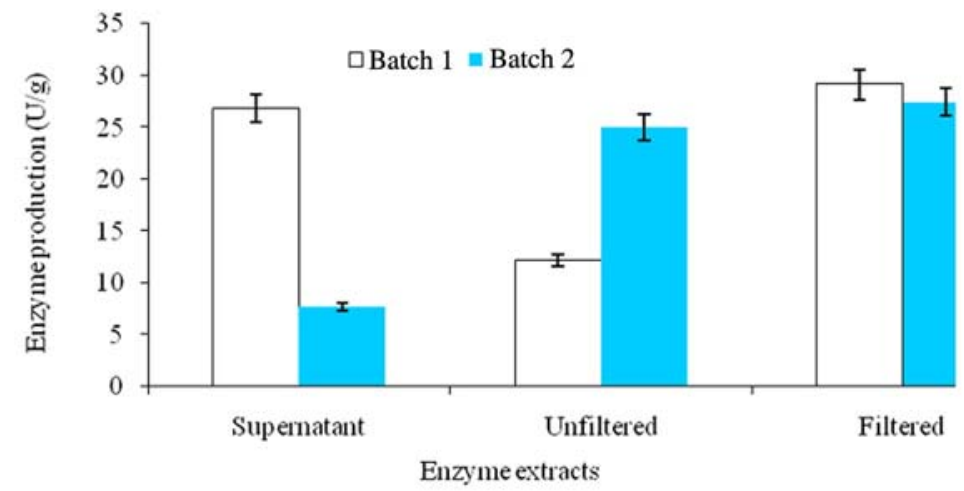

Fig. 2. Effect of different level of diluents on the production of an extracellular laccase from A. nidulans IMPP-0785 under SSF.

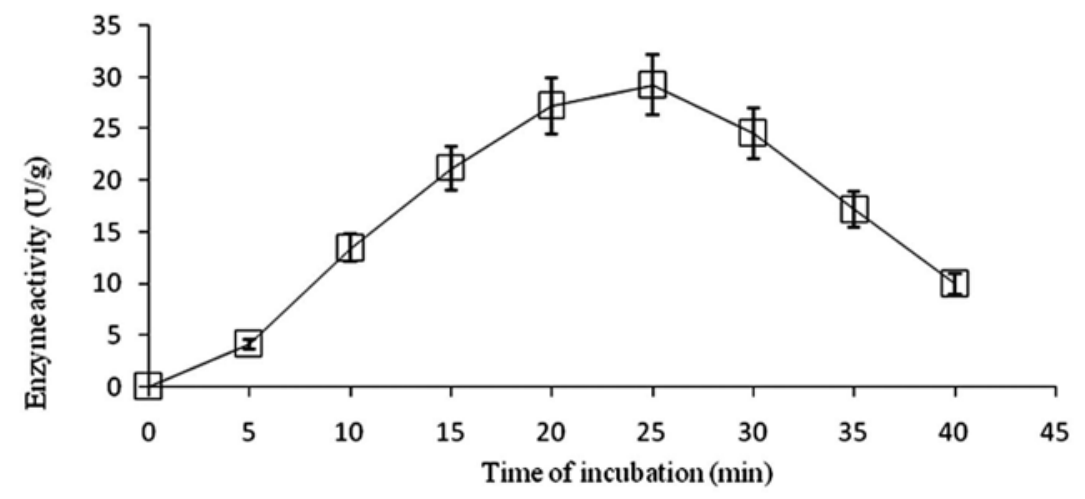

Fig. 3. Effect of different incubation periods on the activity of immobilized laccase from A. nidulans IMPP-0785 under SSF.

Effect to different dilutions of enzyme $(2.5,5,7.5,10,12.5$ and $15 \%)$ was a gradual increase in enzyme activity. Dilution effect increased from 2.5 to $10 \%$ and then abruptly decrease from 12.5 to $15 \%$ dilution factors and minimal activity $(24.25 \mathrm{U} / \mathrm{g}$ ) noticed at $15 \%$ (Fig. 5).

Maximal decolorizing percentage (82.55) was achieved with immobilized laccase of methylene blue and eosin gelblich dye was least decolorized (32.63\%). While malachite green dye decolorized $71.2 \%$ with laccase enzyme (Fig. 6 ). 


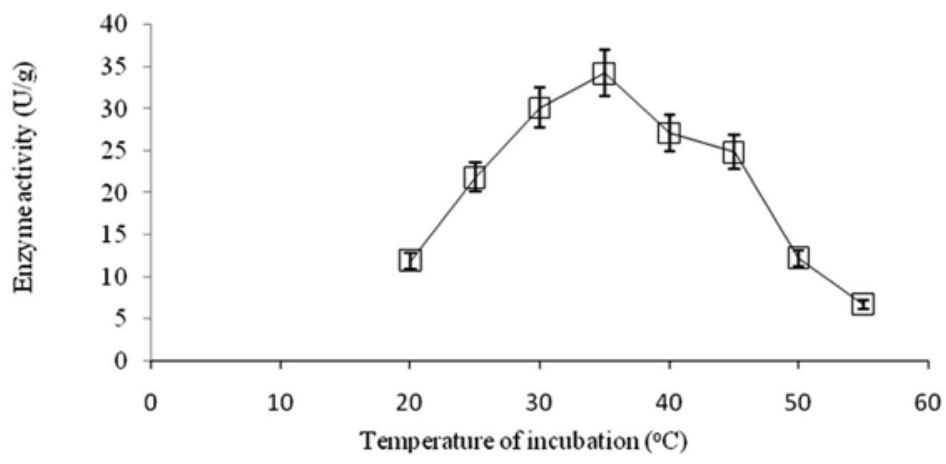

Fig. 4. Effect of temperature on activities and stability of immobilized laccase produced from A. nidulans IMPP-0785 under SSF.

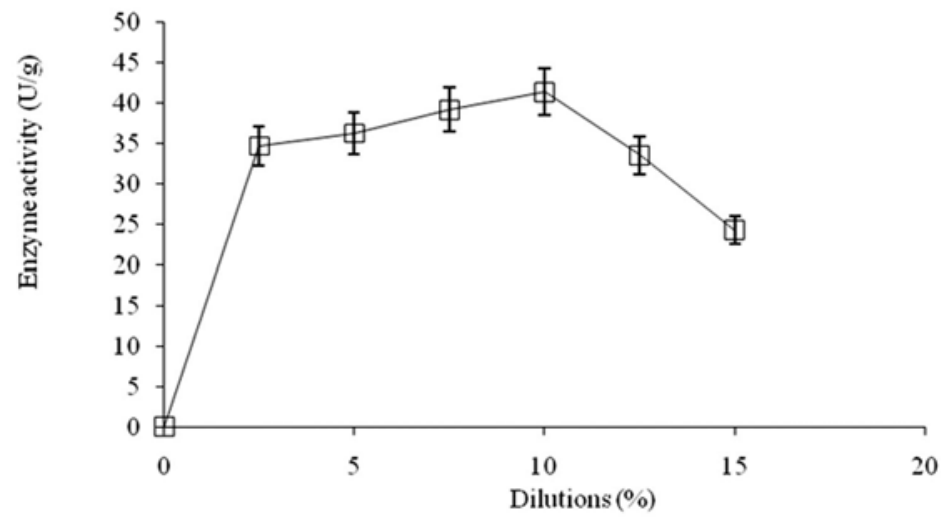

Fig. 5. Effect of different enzyme dilutions on activity of immobilized laccase.

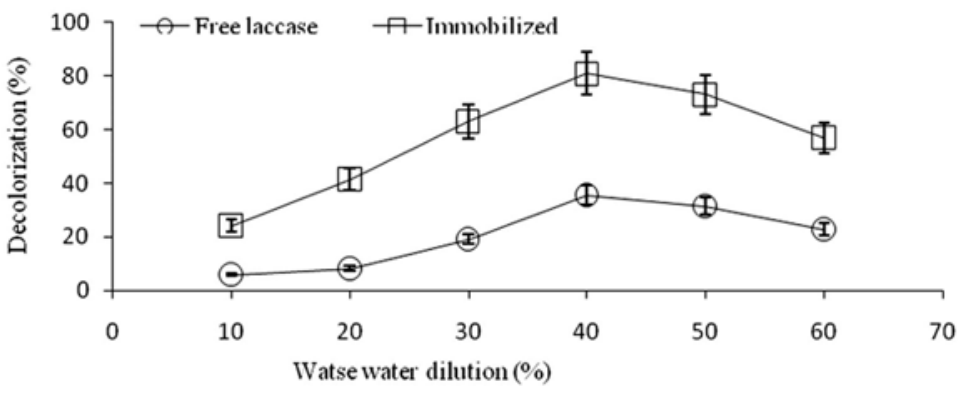

Fig. 6. Effect of free laccase and immobilized laccase on decolorizing activity of different dyes.

Enzyme production, immobilization, time of incubation, different dilutions, thermo stability and decolorizing activity with different dyes and industrial waste water were investigated, respectively. A large number of agricultural wastes are used as substrate for example cotton stalk, molasses waste water, wheat and barley, rice, bran, grape seeds and grape stalks which resulted highest enzyme production (Souza et al. 2002, Couto et al. 2002, Lorenzo et al. 2002 and Chawachart et al. 2004). Barley bran was used for maximum enzyme production as it contained 
$21 \%$ lignin with $75 \%$ moisture content (Pant and Adholeya et al. 2006), production of laccase was found on day 7 as reported by (Xin and Geng et al. 2010). The species of fungus by used Viswanath et al. (2008), Produced more enzyme as compared to the enzymes studied by Pant and Adholeya et al. (2006).

When waste water dilutions $(10,20,30,40,50$ and $60 \%)$ Nishat mills industry LTD were treated with free and immobilized laccase (Fig. 7), the maximal decolorizing per cent was seen with $40 \%$ dilution $(68.64 \%)$ and minimal results were found with 10 time dilution factor (29.42\%). Haroon textile industry LTD waste water dilutions $(10,20,30,40,50$ and $60 \%)$ treated with free and immobilized laccase (Fig. 8a), vital textile industry waste water dilutions (10, 20, 30, 40, 50 and 60\%) treated with free and immobilized laccase (Fig. 8b) With increase in dilution effect activity gradually increase up to $50 \%$ dilution and then at $60 \%$ decolorizing ability was decreased.

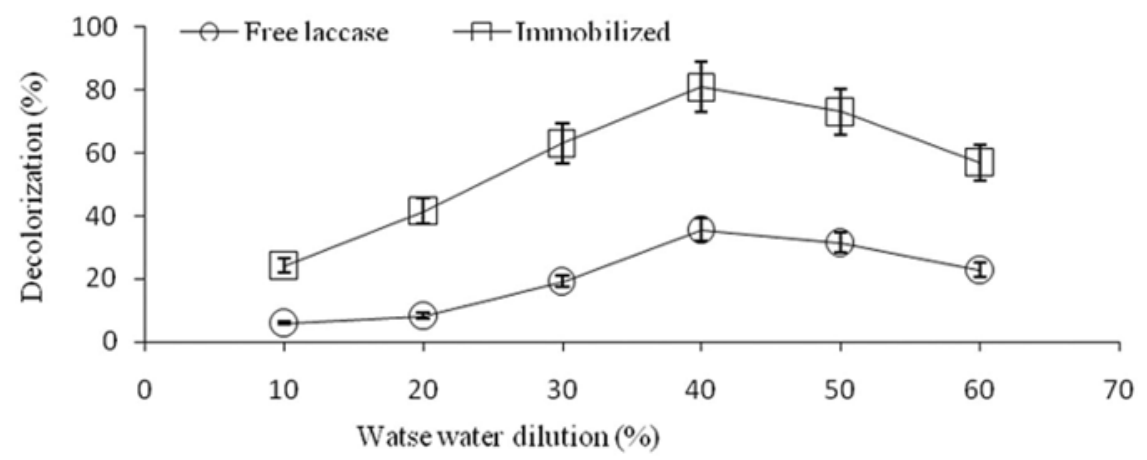

Fig. 7. Effect of free laccase and immobilized laccase on decolorizing activity of Nishat mills industrial waste water concentration.

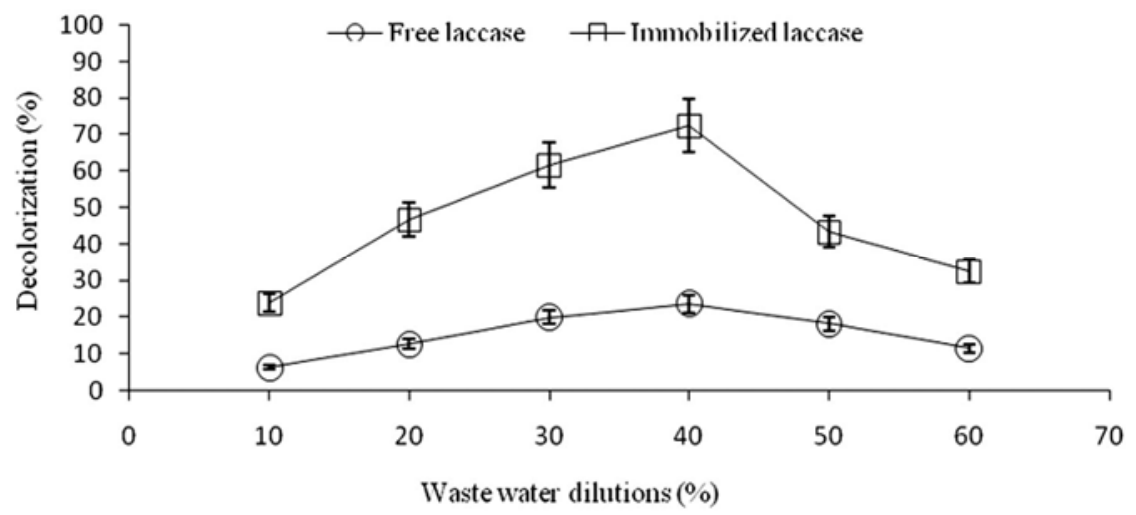

Fig. 8(a). Effect of free laccase and immobilized laccase on decolorizing activity of Haroon textile industrial waste water concentrations.

The immobilization procedure was accomplished by adding alginate to a gelatin solution containing the enzyme and the subsequent dropwise addition of the mixture into stirred $\mathrm{CaCl}_{2}$ solution. The most frequently used stabilization method is immobilization of enzyme and reuse of the catalyst and assistance of reaction control (Cao et al. 2003 and Mateo et al. 2006). Gelatinalginate was prepared by Mogharabi et al. (2012). He entrapped laccase in gelatin-alginate mixed 
gel by adding $0.1 \mathrm{~g}$ sodium alginate to $10 \mathrm{ml}$ of solution with gelatin and laccase range of 5 - 50 $\mathrm{mg}$. Galhaup et al. (2002) obtained a maximum laccase activity of 740,000 U/l by T. pubescens cultured in a 20-1 STR with a stirring speed of $100 \mathrm{rpm}$ and with $2 \mathrm{mM} \mathrm{Cu}^{+2}$ after immobilization of enzyme. Font et al. (2003) obtained a maximum laccase activity of 16,000 U/l by free pellets of T. versicolor in a $0.5-1$ pulsed-bed reactor.

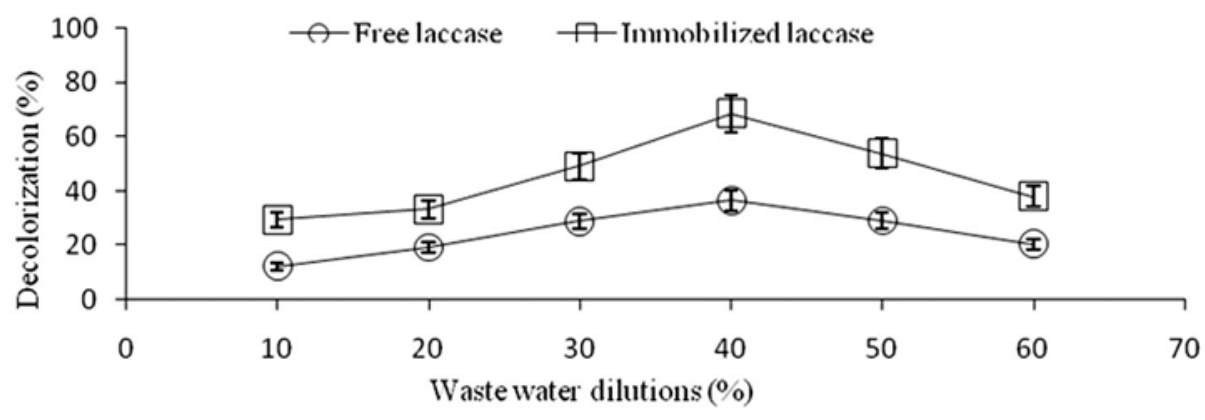

Fig. 8(b). Dye decolorizing effect of immobilized laccase produced from A. nidulans IMPP-0785 under SSF on Vital textile industrial waste water.

Wang et al. (2010) studied decolorization ability of wool dyes by laccase. He used two commercial wool dyes (azo dye diamond black PV and anthraquinone dye weak acid blue AS) and incubated reaction mixture at $20-70^{\circ} \mathrm{C}$. The maximal decolorization rates of tested wool dyes were both observed at $40^{\circ} \mathrm{C}$. The decolorization percentage for weak acid blue AS was more than $88 \%$ after incubation at $40^{\circ} \mathrm{C}$ for $2 \mathrm{hrs}$ at $\mathrm{pH} 4.0$, whereas, it was lower for diamond black PV with only a decolorization percentage of $74.7 \%$ at $40^{\circ} \mathrm{C}$ and $\mathrm{pH} 4.5$.

Similar results were obtained by $\mathrm{Lu}$ et al. (2007), who stabilized enzyme at $25^{\circ} \mathrm{C}$ for $1 \mathrm{hr}$ in the $\mathrm{pH}$ range from 2.0 to 5.0 , an increase in temperature of the fermented mass due to respiration. A. nidulans IMPP-0785 was evaluated at $570 \mathrm{~nm}$ absorption.

Harron and Vital textile industries waste water decolorize maximally at (72.44 and 68.64\%) with immobilized enzyme and (23.66 and 36.61\%) with free laccase at $40 \%$ dilutions, respectively. Dilutions of the entrapped laccase was also studied and the results showed that $10 \%$ concentration gave optimal results (41.36 U/g). Related results were found by Asgher et al. (2012) for different textile industries (Sitara textile, Nishat textile, K\&N textile and Crescent textile units of Faisalabad) effluents.

\section{References}

Arias ME, Arenas M, Rodriguez J, Soliveri J, Ball AS and Hernandez M. 2003. Kraft pulp biobleaching and mediated oxidation of a nonphenolic substrate by laccase from Streptomyces cyaneus CECT 3335 . Appl. Environ. Microbiol. 69(4): 1953-1958.

Asgher MS, Kamal and Iqbal HMN 2012. Improvement of catalytic efficiency, thermo-stability and dye decolorization capability of Pleurotusostreatus IBL-02 laccase by hydrophobic sol gel entrapment. Chem. Cent. J. 6: 110.

Cao L, Langen LV and Sheldon RA 2003 Immobilised enzymes: Carrier-bound or carrier-free? Curren. Opini. Biotechnol. 14: 387-394.

Chawachart N, Khanongnuch C, Watanabe T and Lumyong S 2004. Rice bran as an efficient substrate for laccase production from thermotolerant basidiomycete Coriolus versicolor strain RC3. Fung. Divers. 15: $23-32$ 
Couto SR, Maria G, Miriam L and Sanroman MA 2002. Screening of supports and inducers for laccase production by Trametes versicolor in semi solid conditions. Proc. Biochem. 38: 249-255.

Duran N and Esposito E. 2000. Potential applications of oxidative enzymes and phenoloxidase-like compounds in waste water and soil treatment: a review. Appl. Catalysis B: Environ. 28: 83-99.

Duran N, Rosa MA, D'Annibale A and Gianfreda L. 2002. Applications of laccases and tyrosinases (phenoloxidases) immobilized on different supports: a review. Enzy. Microbiol. Technol. 31: 907-931

Elisashvili V, Kachlishvili E and Penninckx M 2008. Effect of growth substrate, method of fermentation and nitrogen source on lignocellulosic-degrading enzymes production by white-rot basidiomycetes. J. Ind. Microbiol. Biotechnol. 35: 1531-38.

Font X, Caminal G, Gabarrell X, Romer S and Vicent MT 2003. Black liquor detoxification by laccase of Trametes versicolor pellets. J. Chem. Technol. Biotechnol. 78: 548-554.

Galhaup C, Wagner H, Hinterstoisser B and Haltrich D 2002. Increased production of laccase by the wood degrading basidiomycete Trametespubescens. Enzy. Microb. Technol. 30: 529-536.

Gupta VK and Suhas 2009. Application of low-cost adsorbents for dye removal - A review. J. Env. Manage. 90(8): 2313-2342.

Harris ZL, Davis-Kaplan SR, Gitlin JD and Kaplan J 2004. A fungal multicopper oxidase restores iron homeostasis in aceruloplasminemia. Blood. 103: 4672-4673.

Mateo C, Palomo JM, Fernandez-Lorente G, Guisan JM and Fernandez-Lafuente R 2006. Improvement of enzyme activity, stability and selectivity via immobilization techniques. Enzy. Microbiol. Technol. 40: 1451-1463.

Mehdi M, Nasser NK, Maryam BK, Nastaran NV, Ghodsieh B and Mohammad AF 2012. Immobilization of Laccase in alginate-gelatin mixed and decolorization of synthetic Dyes. Bioinorg. Chem. Appl. 1-6.

Nyanhongo GS, Gomesa J, Gubitzc GM, Zvauyab R, Readd J and Steinera W 2002. Decolorization of textiles dyes by laccases from newly isolated strain of Trametes modesta. Water. Resour. 36: 1449-56.

Pant D and Adholeya A 2006. Enhanced production of ligninolytic enzymes and decolorization of molasses distillery waste water by fungi under solid state fermentation. Biodegrad. 18(5): 647-59.

Sinirlioglu ZA, Sinirlioglu D and Akbas F 2013. Preparation and characterization of stable cross-linked enzyme aggregates of novel laccase enzyme from Shewanellaputrefaciens and using malachite green decolorization. Bioresour. Technol. 146: 807-811.

Souza C, Zilly A and Peralta R 2002. Production of laccase as the sole phenoloxidase by a Brazilian strain of Pleurotuspulmonarius in solid state fermentation. J. Basic Microbiol. 42: 83-90.

Viswanath B, Chandra MS, Pallavi H and Reddy BR 2008. Screening and assessment of laccase producing fungi isolated from different environmental samples. Afr. J. Biotechnol. 7(8): 1129-1133.

Wang Z, Cai Y, Liao X, Zhang F, Zhang D and Li Z 2010. Production and characterization of a novel laccase with cold adaptation and high thermal stability from an isolated fungus. Appl. Biochem. Biotechnol. 162(1): 280-294.

Wesenberg D, Kyriakides I and Agathos SN 2003. White-rot fungi and their enzymes for the treatment of industrial dye effluents. Biotechnol. Adv. 22: 161-187.

Xin F and Geng A 2010. Utilization of horticultural waste for laccase production by Trametes versicolor under solid state fermentation. Appl. Biochem. Biotechnol. 163: 235-246.

(Manuscript received on 3 May, 2018; revised on 25 May, 2018) 